\title{
Evaluation of Echinacea Immunomodulatory Effect on the Immune Response of Broiler Chickens
}

Enany, M.E. ${ }^{1}$; Algammal, A.M. ${ }^{l}$; Solimane, R.T ${ }^{2}$; El-Sissi, A.F. ${ }^{3}$ and Hebashy A.A. ${ }^{3}$

${ }^{1}$ Department of Bacteriology, Immunology and Mycology, Faculty of Veterinary Medicine, Suez Canal University ${ }^{2}$ Department of Microbiology, Faculty of Veterinary Medicine, Cairo University

${ }^{3}$ Department of Immunology, Animal Health Research Institute, Dokki

\section{Abstract}

Immunomodulators provide an excellent approach as they mainly have fewer side effects than chemical drugs and have no affinity for creating microbial resistance. In order to investigate the Echinacea immunomodulatory effect on the immune response of broiler chickens, one hundred twenty (1-day-old) chicks of both sexes were randomly allocated into 2 dietary groups on floor pen (60 chicks/group), group1: Chicks were offered basal diets and kept as control group, group2: Chicks were offered basal diets supplemented with Echinacea purpurea $(5 \mathrm{gm} / \mathrm{kg}$ diet for 6 weeks). Evaluating the effects of Echinacea purpurea on growth performance, Serum Protein profile, total and differential leucocytic count, humeral immunity which was carried out by measuring antibody titer against Newcastle (ND) and (AIV) Avian Influenza vaccine, and on innate immunity which was carried by measuring some function of peripheral blood monocyte (PBM) as phagocytic activity, fungicidal activity, nitric oxide NO production and reactive oxygen species ROS production. Challenge test was carried out using virulent $E$. coli strain. The results revealed that, Echinacea improve growth performance, significantly increase antibody titer against ND and AIV vaccine as well as enhance the innate immunity by increasing the phagocytic activities, fungicidal activities, ROS production and nitric oxide production of monocytes. In challenge test, Echinacea reduce $E$. coli lesions, morbidity and mortality rate. Based on the results of this study, it could be concluded that growth performance and both humeral and innate immune responses of broiler chicks were improved by of dietary supplementation of Echinacea purpurea ( $5 \mathrm{~g} / \mathrm{kg}$ diet), also it could protect broiler chickens from virulent $E$. coli infection.

Key words: Echinacea, broiler chickens, E. coli, humeral immunity, innate immunity challenge test. 


\section{Introduction}

The use of antibiotic in treatment of various bacterial diseases has an important concern in human health and animal production. The use of dietary antibiotics in feed to promote growth of poultry and other livestock has been implicated in the increased microbial resistance and the rise in number of human patients infected with these pathogens (Threlfall et al., 2000 and Teuber, 2001).

The social pressure to reduce and completely eliminate the use of antibiotics in poultry feed has increased; food safety standards have also been heightened recently (USDA FSIS, 2010). Dietary immunomodulation is an important method used for decreasing the prevalence of food borne pathogens in poultry .One of the most popular natural immunomodulator is Echinacea purpurea. This herbal immunomodulator has been used from long period of time for many purposes including immunostimulation, therapy and growth promotion (Barrett, 2003; Porchezhian and Punniamurthy, 2006).

Echinacea purpurea is mainly used globally for stimulation of immune system. It is a natural drug used in treatment of respiratory manifestations, cancer and inflammatory lesions. Many of the active ingredients of Echinacea have been recognized including; polysaccharides, alkylamides, chicoric acid, arabinogalactan and glycoproteins. The percentage of these constituents varies depending on which part of Echinacea was analyzed (Percival, 2000; Redondo, 2000). Echinacea could be used in increasing the immune response, especially of cells such as neutrophils, monocytes and lymphocytes (O'Neill et al., 2002; Cundell et al., 2003).

Echinacea extracts have the ability to increase the antibody titer against antigens, such as keyhole hemocyanin and sheep RBCs, in sera of the tested animals. The root extracts enhance the production of cytokines, such as IL-1, IL-10 and TNF- $\alpha$ by human macrophages (Currier and Miller, 2002; Mishima et al., 2004).

This work was planned to evaluate the effect of dietary supplementation of Echinacea on innate and humeral immunity of broiler chickens, as well as the antibacterial effect of Echinacea against $E$. coli (in vivo) by challenge test.

\section{Materials and Methods}

\section{Experimental design:}

One hundred twenty (1-day-old) chicks (Hubbard breed) of both sexes were randomly allocated into 2 dietary groups on floor pen (60 chicks/group). Group1 (G1): broiler chicks were offered basal diets and kept as a control group. Group2 (G2): broiler chicks in this group were offered basal diets supplemented with Echinacea 
(5gm/ $\mathrm{kg}$ diet for 6 weeks) (Landy et al., 2011).

2. Determination of growth Performance Parameters:

Birds were weighed at first day of age as one day-old weight and then final body weights (gm) were recorded at 42 days of age.

\section{Blood sampling:}

Blood samples were collected from the 2 groups, and divided into 3 portions; the first portion was collected in plain tubes, for separation of serum and kept frozen at $-20^{\circ} \mathrm{C}$ tell use. The $2^{\text {nd }}$ portion was collected in EDTA tubes for leucocytic count. The $3^{\text {rd }}$ portion was collected in heparinized tubes and was used for separation of peripheral blood monocyte cells (PBM) according to (Grievink et al., 2016).

4. Determination of total and differential leucocytic count:

The total and differential leucocytic counts were determined at the $1^{\text {st }}$, $2^{\text {nd }}$ and $4^{\text {th }}$ week according to

(Stoskopf, 1993).

5. Determination of protein profile:

5.1. Determination of serum total protein:

Serum total protein concentration was determined at $1^{\text {st }}, 2^{\text {nd }}$ and $4^{\text {th }}$ week as described by (Bakerman, 1984).

5.2. Determination of serum albumin:

Serum albumin was determined at $1^{\text {st }}, 2^{\text {nd }}$ and $4^{\text {th }}$ week, according to the method of (Young, 1997).
5. 3.Calculation of serum globulin:

Serum globulin was estimated at $1^{\text {st }}$, $2^{\text {nd }}$ and $4^{\text {th }}$ week, by subtracting the concentration of albumin from the value of estimated total protein.

\section{4. $\mathrm{A} / \mathrm{G}$ ratio:}

Albumin/ globulin were estimated at $1^{\text {st }}, 2^{\text {nd }}$ and $4^{\text {th }}$ week by dividing value of albumin over globulin.

\section{Evaluation of humeral immune} response of chicks:

Humeral immune response was evaluated at $1^{\text {st }}, 2^{\text {nd }}, 3^{\text {rd }}$ and $4^{\text {th }}$ week by detecting antibody titer against ND and AI virus vaccine by haemagglutination inhibition test according to (Miller, 2013).

7. Estimation of Innate immune response:

7.1. Determination of phagocytic activity:

The phagocytic activity of monocyte cells was assessed according to Elmowalid (2012), at $1^{\text {st }}, 2^{\text {nd }}, 4^{\text {th }}$ and $6^{\text {th }}$ week of age. The results are expressed as phagocytic percentage (number of phagocytic monocytes /total number of monocytes) and phagocytic index (the main of engulfed Candida spores per monocyte).

\subsection{Fungicidal activity} (Intracellular survival assay):

An intracellular survival assay was used to measure the fungicidal activity of monocytes at $2^{\text {nd }}, 4^{\text {th }}$ and $6^{\text {th }}$ week of age, according to (Peck, 1985).

7.3. Nitric oxide assay:

Nitric oxide production was measured in PBM culture media 
using Griess reagent at $1^{\text {st }}, 2^{\text {nd }}, 4^{\text {th }}$ and $6^{\text {th }}$ week as described by (Blond et al., 2000).

7.4. Reactive oxygen species production:

The reactive oxygen species production of PBM were determined using Nitro blue tetrazolium reduction test at $2^{\text {nd }}, 3^{\text {rd }}$ and $6^{\text {th }}$ week of age, as described by (Anderson and Siwicki, 1995).

\section{Challenge Test:}

Laboratory multidrug resistant virulent E. coli strain was used at the end of the experiment for challenge test. The clinical symptoms were recorded since the first day of chicken inoculation for calculation of morbidity and mortality rate, the survived chickens were slaughtered and the internal organs were harvested and prepared to determine total CFU count in each organ of each chicken in each experimental group.

\section{Statistical analysis:}

The data were given as means \pm S.E. The statistical analysis was done using the One Way ANOVA. The significant $\left({ }^{*} \boldsymbol{P}\right)$ values were taken as $\boldsymbol{P} \leq 0.05$ (McCredie et al., 2006).

\section{Results}

\section{1-Effect of dietary} supplementation with Echinacea on body weight gain in broiler chickens:

The results showed in Table (1) revealed that chickens in G2 fed Echinacea supplemented diet for 42 days showed a significant increase in final body weight and body weight gain compared to control group.

2- Effect of dietary supplementation with Echinacea on total and differential leucocytic count in broiler chickens:

The obtained results in Table (2) revealed that there was a significant increase in total leucocytic count in chickens which fed on a ration containing Echinacea at all intervals compared with the control group.

The heterophilic count of chickens which fed a ration containing Echinacea at $1^{\text {st }}, 2^{\text {nd }}$ and $4^{\text {th }}$ week in Table (2) revealed that there was a significant increase in the heterophilic count in chickens which fed on a ration containing Echinacea at all the experimental period when compared with the control group.

The lymphocytic count of chickens which fed a ration containing Echinacea in Table (2) revealed that there was significant increase in the lymphocytic count in chickens which fed on a ration containing Echinacea at all the experimental period when compared with the control group.

The monocytic count of chickens which fed a ration containing Echinacea .The obtained results in Table (2) revealed that there was non-significant increase in monocytic count in chicks fed on ration containing Echinacea when compared with the control group. 
The eosinophilic count of chickens which fed supplemented diet with Echinacea

in Table (2) revealed that there was non-significant alterations in the eosinophilic count in chicks fed supplemented diet Echinacea when compared with the control group.

3- Effect of dietary supplementation with Echinacea on total protein (gm/dl), albumin $(\mathrm{gm} / \mathrm{dl})$ and globulin $(\mathrm{gm} / \mathrm{dl})$ in broiler chickens:

The mean values of the proteinogram of chicken's fed supplemented diets with Echinacea were tabulated in Table (3). There were no significant changes in the total proteins and albumin at $1^{\text {st }}$ and $4^{\text {th }}$ week from dietary supplementation in the 2 groups. There were insignificant changes in globulins at $1^{\text {st }}$ week in all groups, while there was significant increase at $4^{\text {th }}$ week in the chickens fed supplemented diet with Echinacea when compared with the control group. A/G ratio at ${ }^{1 \text { st }}$ and ${ }^{\text {th }}$ week there were significant decrease at chickens fed supplemented diet with Echinacea when compared with the control group.

4- Effect of dietary supplementation with Echinacea on the antibodies titers of Newcastle and AI viruses' vaccine of broiler chickens:

Results shown in Table (4) revealed that chickens fed on Echinacea supplemented diet showed significant increase in antibody titer of ND and AI vaccines at $3^{\text {rd }}$ and $4^{\text {th }}$ week post vaccination compared to the control group.

3-Effect of dietary supplementation with Echinacea on the innate immunity of broiler chickens:

5.1- phagocytic activity of peripheral blood monocyte:

The phagocytic activity of monocyte cells of chickens fed Echinacea supplemented diet Table (5) and Photo(1), showed significant increase in the phagocytic $\%$ at $4^{\text {th }}$ and $6^{\text {th }}$ week, and significant increase in phagocytic index at all over the experimental duration compared to the control group.

5.2- Fungicidal activity of the peripheral blood monocyte:

Fungicidal \% of the PBM showed a significant increase in G2, Echinacea treated group, compared to control group at $2^{\text {nd }}, 4^{\text {th }}$ and $6^{\text {th }}$ weeks (Table 6).

5.3- Nitric oxide production $(\mu \mathrm{mol} / \mathrm{ml})$ of the peripheral blood monocytes:

The data recorded in Table (6) revealed that, chickens fed diet supplemented by Echinacea (2) showed a significant increase in $\mathrm{NO}$ at $4^{\text {th }}$ and $6^{\text {th }}$ weeks compared with the control group.

5.4- Reactive oxygen species production (OD) of the peripheral blood monocytes:

By using nitro blue tetrazolium reduction test, ROS production of PBM of chickens fed Echinacea supplemented diet showed a significant increase on ROS 
production at $6^{\text {th }}$ weeks compared to control group (Table 6 and photo2).

6-Effect of

supplementation of broiler chickens with Echinacea on susceptibility to infections (challenge test):

Clinical signs of E.coli infection were observed on both challenged groups within 2-3 days post infection, including; fever, ruffling feather, weight loss, and diarrhea, which were more severe in control group than that fed Echinacea supplemented diet, morbidity rate was $80 \%$ in control group, while it was (46.7\%) in Echinacea in supplemented group. Mortality rate was $(60 \%)$ in the control group (9/15 were died within 10 days post challenge), while it was $(26.7 \%)$ chickens died in the Echinacea dietary supplemented group (4/15 were died after 10 days) as shown in Table (7). The results shown in Table (8) revealed that there was a significant reduction in $E$. coli count in the spleen, liver and intestine of chickens fed on supplemented ration with Echinacea when compared with the control group.

Table (1): Effect of dietary supplementation with Echinacea on growth performance of broiler chicks:

\begin{tabular}{|l|c|c|c|}
\hline \multicolumn{1}{|c|}{ Group } & Initial body weight $(\mathbf{g})$ & $\begin{array}{c}\text { Final body weight } \\
(\mathbf{g})\end{array}$ & body weight gain $(\mathbf{g})$ \\
\hline Control & $46.00 \pm 0.67^{\mathbf{a}}$ & $1779.40 \pm 5.89^{\mathbf{b}}$ & $1731.79 \pm 5.05^{\mathbf{b}}$ \\
\hline Echinacea & $46.91 \pm 0.38^{\mathbf{a}}$ & $2220.97 \pm 46.87^{\mathbf{a}}$ & $2173.79 \pm 14.58^{\mathbf{a}}$ \\
\hline
\end{tabular}

*Data are presented as (means \pm S.E) *Means with different superscript letters in the same column are significantly different at $(\boldsymbol{P} \leq 0.05)$.

Table (2): Effect of dietary supplementation with Echinacea on total and differential leucocytic count in broiler chickens:

\begin{tabular}{|c|c|c|c|c|c|c|c|c|c|c|c|c|c|c|c|}
\hline \multirow[b]{2}{*}{ : } & \multicolumn{3}{|c|}{ TLC } & \multicolumn{3}{|c|}{ Heterophils } & \multicolumn{3}{|c|}{ Lymphocytes } & \multicolumn{3}{|c|}{ Monocytes } & \multicolumn{3}{|c|}{ Eosinophils } \\
\hline & 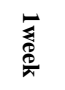 & 晜 & 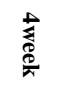 & 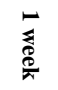 & 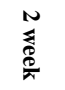 & 逽 & $\frac{7}{\not{z}}$ & 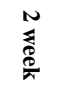 & 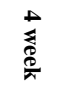 & 咅 & 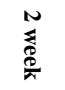 & 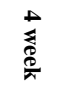 & $\begin{array}{l}\vec{Z} \\
\frac{D}{\pi}\end{array}$ & 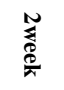 & 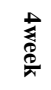 \\
\hline$\frac{\varrho}{\underline{\underline{g}}}$ & 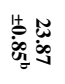 & 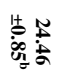 & 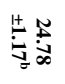 & 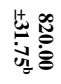 & 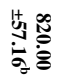 & 壳范 & 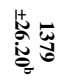 & $\begin{array}{l}\text { 蒡志 } \\
\text { 怘 }\end{array}$ & 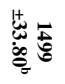 & 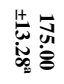 & 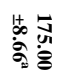 & 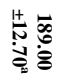 & 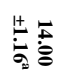 & 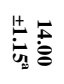 & 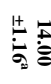 \\
\hline 莍 & 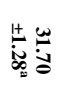 & 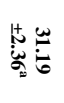 & 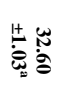 & 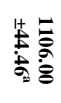 & 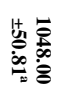 & 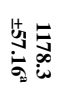 & 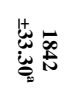 & 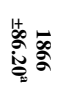 & 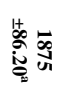 & 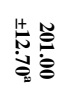 & 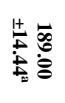 & غ & 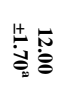 & 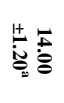 & 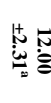 \\
\hline
\end{tabular}

$*$ Data are presented as (means \pm S.E) *Mean with different superscript letters in the same column is significantly different at $(\boldsymbol{P} \leq 0.05)$. 
Table (3): Effect of dietary supplementation with Echinacea on proteinogram of broiler chickens:

\begin{tabular}{|c|c|c|c|c|c|c|c|c|}
\hline $\begin{array}{l}\text { Parameters } \\
\text { Group }\end{array}$ & $\begin{array}{c}\text { Total } \\
\text { protein } \\
\text { (gm/dl) } \\
\text { 1week }\end{array}$ & $\begin{array}{c}\text { Total } \\
\text { protein } \\
(\mathrm{gm} / \mathrm{dl}) \\
4 \text { week }\end{array}$ & $\begin{array}{c}\text { Albumin } \\
\text { (gm/dl) } \\
1 \text { week }\end{array}$ & $\begin{array}{c}\text { Albumin } \\
(\mathrm{gm} / \mathrm{dl}) \\
4 \text { week }\end{array}$ & $\begin{array}{c}\text { Globulin } \\
\text { (gm/dl) } \\
1 \text { week }\end{array}$ & $\begin{array}{c}\text { Globulin } \\
\text { (gm/dl) } \\
\text { 4week }\end{array}$ & $\begin{array}{c}\text { A/G } \\
\text { ratio } \\
1 \text { week }\end{array}$ & $\begin{array}{l}\text { A/G } \\
\text { ratio } \\
4 \\
\text { week }\end{array}$ \\
\hline Control & $\begin{array}{c}3.68 \\
\pm 0.30^{\mathrm{a}} \\
\end{array}$ & $\begin{array}{c}4.54 \\
\pm 0.21^{\mathrm{a}} \\
\end{array}$ & $\begin{array}{c}1.99 \\
\pm 0.12^{\mathrm{a}} \\
\end{array}$ & $\begin{array}{c}2.08 \\
\pm 0.17^{\mathrm{a}} \\
\end{array}$ & $\begin{array}{c}1.69 \\
\pm 0.06^{\mathrm{a}} \\
\end{array}$ & $\begin{array}{c}2.46 \\
\pm 0.05^{\mathrm{a}} \\
\end{array}$ & $\begin{array}{c}1.17 \\
\pm 0.05^{\mathrm{a}} \\
\end{array}$ & $\begin{array}{c}0.85 \\
\pm 0.02^{\mathrm{a}} \\
\end{array}$ \\
\hline Echinacea & $\begin{array}{c}3.96 \\
\pm 0.16^{\mathrm{a}}\end{array}$ & $\begin{array}{c}4.91 \\
\pm 0.17^{\mathrm{a}}\end{array}$ & $\begin{array}{c}1.94 \\
\pm 0.12^{\mathrm{a}}\end{array}$ & $\begin{array}{c}2.00 \\
\pm 0.12^{\mathrm{a}}\end{array}$ & $\begin{array}{c}2.02 \\
\pm 0.07^{\mathrm{a}}\end{array}$ & $\begin{array}{c}2.91 \\
\pm 0.05^{b}\end{array}$ & $\begin{array}{c}0.96 \\
\pm 0.03^{\mathrm{b}}\end{array}$ & $\begin{array}{c}0.69 \\
\pm \\
0.03^{\mathbf{b}} \\
\end{array}$ \\
\hline
\end{tabular}

*Data are presented as (means \pm S.E) *Mean with different superscript letters in the same column are significantly different at $(\boldsymbol{P} \leq 0.05)$.

Table (4): Effect of dietary supplementation with Echinacea on the antibody titer (log2 HI titer) against Newcastle and Avian influenza viruses at different ages:

\begin{tabular}{|l|c|c|c|c|c|c|c|c|}
\hline Type & \multicolumn{9}{|c|}{ ND antibody } & \multicolumn{4}{c|}{ AIV antibody } \\
\hline \multirow{3}{*}{ Group } & 1 week & 2week & 3week & 4Week & 1 week & 2 week & 3 week & 4week \\
Age & & & & & & & & \\
\hline Control & $4.26 \pm$ & $4.26 \pm 0.10^{\mathrm{b}}$ & $5.89 \pm 0.17^{\mathrm{b}}$ & $6.47 \pm 0.23^{\mathrm{b}}$ & $5.19 \pm$ & $2.26 \pm$ & $3.77 \pm$ & $4.81 \pm 0.21^{\mathrm{b}}$ \\
& $0.21^{\mathrm{a}}$ & & & & $0.23^{\mathrm{a}}$ & $0.07^{\mathrm{b}}$ & $0.32^{\mathrm{b}}$ & \\
\hline & $4.06 \pm$ & $5.18 \pm$ & $6.77 \pm$ & $7.12 \pm$ & $5.73 \pm$ & $2.74 \pm 0.17^{\mathrm{a}}$ & $4.45 \pm$ & $6.18 \pm$ \\
Echinacea & $0.13^{\mathrm{a}}$ & $0.07^{\mathrm{a}}$ & $0.19^{\mathrm{a}}$ & $0.16^{\mathrm{a}}$ & $0.21^{\mathrm{a}}$ & & $0.16^{\mathrm{a}}$ & $0.25^{\mathrm{a}}$ \\
\hline
\end{tabular}

*Data are presented as (means \pm S.E) *Mean with different superscript letters in the same column is significantly different at $(\boldsymbol{P} \leq 0.05)$.

Table (5): Effect of dietary supplementation of Echinacea on phagocytic \%and phagocytic index of the peripheral blood monocytes of broiler chickens:

\begin{tabular}{|c|c|c|c|c|c|c|c|c|}
\hline Type & \multicolumn{5}{|c|}{ Phagocytic \% } & \multicolumn{5}{c|}{ Phagocytic index } \\
\hline $\begin{array}{c}\text { Age } \\
\text { Group }\end{array}$ & 1week & 2week & 4week & 6week & 1 week & 2 week & 4week & 6 week \\
\hline & & & & & & & & \\
Control & $55.00 \pm$ & $53.00 \pm$ & $57.00 \pm$ & $56.00 \pm$ & $3.10 \pm$ & $3.40 \pm$ & $2.90 \pm$ & $2.80 \pm$ \\
& $2.85^{\mathrm{a}}$ & $2.66^{\mathrm{a}}$ & $2.19^{\mathrm{b}}$ & $1.54^{\mathrm{b}}$ & $0.17^{\mathrm{b}}$ & $0.17^{\mathrm{b}}$ & $0.10^{\mathrm{b}}$ & $0.09^{\mathrm{b}}$ \\
\hline \multirow{2}{*}{ Echinacea } & $54.00 \pm$ & $58.00 \pm$ & $68.00 \pm$ & $68.00 \pm$ & $4.50 \pm$ & $4.80 \pm$ & $4.60 \pm$ & $5.10 \pm$ \\
& $3.21^{\mathrm{a}}$ & $2.07^{\mathrm{a}}$ & $2.19^{\mathrm{a}}$ & $2.29^{\mathrm{a}}$ & $0.25^{\mathrm{a}}$ & $0.21^{\mathrm{a}}$ & $0.19^{\mathrm{a}}$ & $0.21^{\mathrm{a}}$ \\
\hline
\end{tabular}

*Data are presented as (means \pm S.E) *Means with different superscript letters in the same column are significantly different at $(\boldsymbol{P} \leq 0.05)$. 
Table (6): Effect of dietary supplementation with Echinacea on Fungicidal activity, Nitric oxide production and reactive oxygen species (ROS):

\begin{tabular}{|c|c|c|c|c|c|c|c|c|c|}
\hline Test & \multicolumn{3}{|c|}{ Fungicidal \% } & \multicolumn{3}{|c|}{$\mathrm{NO}(\mu \mathrm{mol} / \mathrm{ml})$} & \multicolumn{3}{|c|}{$\operatorname{ROS}(\mathrm{OD})$} \\
\hline Group & 2week & 4week & 6week & 2week & 4week & 6week & 2week & 4week & 6week \\
\hline Control & $\begin{array}{r}43.00 \\
\pm 2.48^{\mathrm{b}}\end{array}$ & $\begin{array}{c}53.00 \\
\pm 2.24^{\mathrm{b}}\end{array}$ & $\begin{array}{c}52.00 \\
\pm 1.54^{\mathrm{b}}\end{array}$ & $\begin{array}{c}23.90 \\
\pm 0.34^{\mathrm{a}}\end{array}$ & $\begin{array}{c}32.10 \\
\pm 1.36^{\mathrm{b}}\end{array}$ & $\begin{array}{c}29.50 \\
\pm 1.28^{\mathrm{b}}\end{array}$ & $\begin{array}{c}0.034 \\
\pm 0.003^{\mathrm{b}}\end{array}$ & $\begin{array}{c}0.038 \\
\pm 0.002^{\mathrm{b}}\end{array}$ & $\begin{array}{c}0.037 \\
\pm 0.002^{\mathrm{b}}\end{array}$ \\
\hline Echinacea & $\begin{array}{r}76.00 \\
\pm 3.18^{\mathrm{a}}\end{array}$ & $\begin{array}{l}81.00 \\
\pm 1.54^{\mathrm{a}}\end{array}$ & $\begin{array}{r}89.00 \\
\pm 1.83^{\mathrm{a}}\end{array}$ & $\begin{array}{c}20.40 \\
\pm 0.30^{\mathrm{a}}\end{array}$ & $\begin{array}{c}36.00 \\
\pm 1.70^{\mathrm{a}}\end{array}$ & $\begin{array}{c}36.90 \\
\pm 1.24^{\mathrm{a}}\end{array}$ & $\begin{array}{c}0.057 \\
\pm 0.002^{\mathrm{a}}\end{array}$ & $\begin{array}{c}0.049 \\
\pm 0.002^{\mathrm{a}}\end{array}$ & $\begin{array}{c}0.061 \\
\pm 0.002^{\mathrm{a}}\end{array}$ \\
\hline
\end{tabular}

*Data are presented as (means \pm S.E) *Mean with different superscript letters in the same column are significantly different at $(\boldsymbol{P} \leq 0.05)$.

Table (7): Effect of dietary supplementation of Echinacea on mortality and morbidity rate of brioler chickens after challenge with E.coli:

\begin{tabular}{|l|c|c|}
\hline $\begin{array}{l}\text { Group } \\
\text { Parameter }\end{array}$ & Control & Echinacea \\
\hline Total No & 15 & 15 \\
\hline Morbidity rate & 12 & 7 \\
\hline Morbidity \% & $80 \%$ & $46.7 \%$ \\
\hline Mortality rate & 9 & 4 \\
\hline Mortality \% & $60 \%$ & $26.7 \%$ \\
\hline
\end{tabular}

Table (8): Effect of dietary supplementation of Echinacea on CFU of E.coli in involved organs of broiler chickens:

\begin{tabular}{|l|c|c|c|}
\hline Group & Organ & Spleen & Intestine \\
\hline Control & $14 \times 10^{6} \pm 577530^{\mathrm{a}}$ & $21 \times 10 \pm 11574^{\mathrm{a}}$ & $16 \times 10^{6} \pm 1154700^{\mathrm{a}}$ \\
\hline Echinacea & $6 \times 10^{5} \pm 28867^{\mathrm{c}}$ & $7 \times 10^{3} \pm 288.70^{\mathrm{b}}$ & $12 \times 10^{3} \pm 577.35^{\mathrm{b}}$ \\
\hline
\end{tabular}

*Data are presented as (means \pm S.E) *Mean with different superscript letters in the same column is significantly different at $(\boldsymbol{P} \leq 0.05)$. 


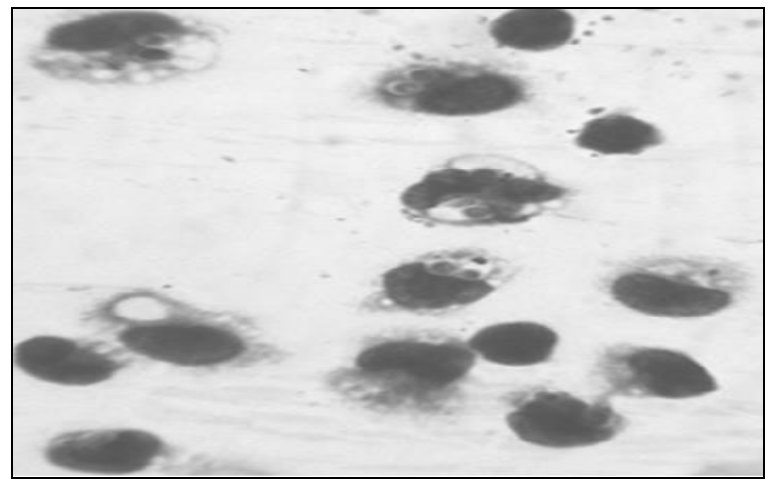

Figure (1): Effect of dietary supplementation of Echinacea on phagocytic activity :(Giemsa stain X 100).

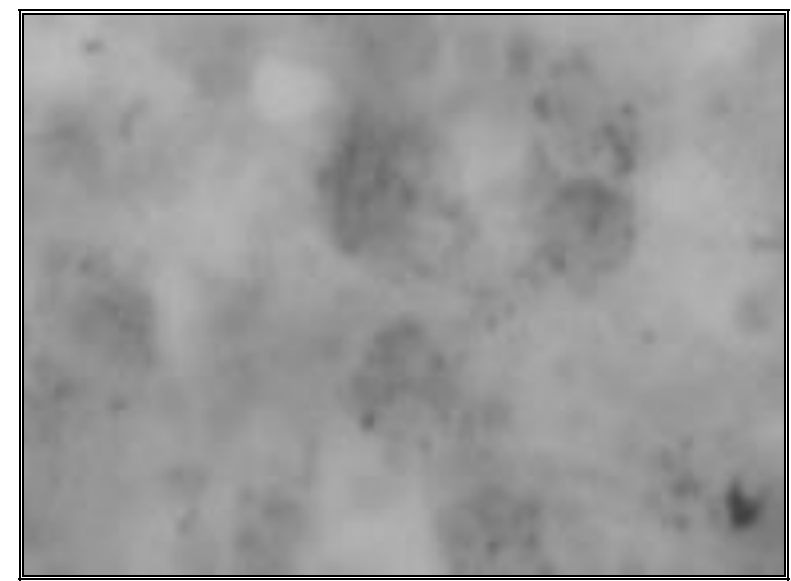

Figure (2): Peripheral blood monocytes cells of broiler chickens fed Echinacea supplemented diet have blue formazne deposit granules (Leishman's stain 100x).

\section{Discussion}

In the present work, Echinacea provided a significant improvement in the final body weight and body weight gain as shown in Table (1), these results are in agreement with the findings of (Jahanian et al., 2014 and Maisa and Fatma, 2014), other researchers (Roth et al., 2005 and Bóhmer et al., 2009) reported that the using of Echinacea as a feed additive for broilers and layers is not beneficial for growth or layer performance. The main causes for this discrepancy in recorded results are the plant origin, climate conditions, host species, the host health status and disease occurrence. (Maass et al., 2005). The mode of action of the herb mixtures on feed conversion is through the enhancement of the digestive functions (Przybilla and Weiss, 1998).

Concerning the leucogram of the broiler chickens, the results shown in 
Table (2) revealed that the dietary supplementation of Echinacea purpurea resulted in asignificant increase in total leucocytic counts as well as the neutrophils and lymphocytic count. These results are in agreement with those obtained by Maisa et al. (2014) who found a significant increase of lymphocytes in broiler chicks supplemented diet with Echinacea purpurea as $5 \mathrm{mg} / \mathrm{kg}$ feed and Barbara et al. (2009) who recorded significant increase in lymphocytes and total leucocytic count in groups receiving ethanolic juice of Echinacea purpurea for 5 days. Echinacea purpurea extract from root significantly increased in vivo the number of leucocytes and lymphocytes of rats (Skaudickas et al., 2003). Moreover, the various immune cells (macrophages, monocytes and natural killer cells) were stimulated in vitro by Echinacea purpurea extract (O'Neill et al., 2002 and Cundell et al., 2003).

Serum proteins were synthesized in liver so it used as indicators of metabolic and synthetic activity of liver. Enhancement of immunoglobulin production leads to increase in serum globulin contents, which represent status of immune health. Regarding the effect of Echinacea on the proteinogram of the treated boiler chicken as shown in Table (3) only treated group with Echinacea showed anumerical increase in serum total protein level which is attributed to a significant increase in serum globulin in the $4^{\text {th }}$ week. These findings are in agreement with those obtained by (Nasir, 2009 and Miraghaee et al., 2011) who reported that Echinacea application improved serum globulin concentration.

In order to evaluate the effect of dietary supplementation of Echinacea purpurea on humoral immune response of broiler chickens, antibody titers against ND and AI $\mathrm{V}$-vaccines were measured. In the present work, broiler chicks fed supplemented diet with Echinacea purpurea showed significant increase in antibody titer against ND and AI as shown in Table (4).These findings are in accordance with that reported by (Dehkordi et al., 2011; Landy et al., 2011). Dried extract of Echinacea purpurea can stimulate the immune system and increase the immune response of Newcastle vaccination (Feizi and Dadian, 2012).

In the present study, as shown in (Table 5 and photo 1), there is a marked increase in the phagocytic $\%$ and index in experimental group compared to the control group. These results are in agreement with those obtained by Allen (2003). The increase of phagocytic activity associated with Echinacea are exactly linked with its active ingredients including; polysaccharides, glycoproteins, and alkylamides of $E$. purpurea (Barrett, 2003).

In the present study (Table 6), the chickens in Echinacea treated group 
showed a significant increase in the fungicidal $\%$ of PBM compared to control group. These results are in agreement with those obtained by Hudson (2012). It was known that Echinacea extracts have a powerful antimicrobial activity (Goel et al., 2002).

Regarding to NO production (Table 6), chickens fed supplemented diet with Echinacea showed significant elevation in NO value at $4^{\text {th }}$ and $6^{\text {th }}$ weeks of age, This was agree with Goel et al. (2002) who reported that Echinacea stimulates macrophage function in the lung and spleen of normal rats, this is due to the effects of active components of Echinacea as cichoric acid, polysaccharides and alkylamides. Moreover, these finding are disagree with those obtained by Tyler et al. (2012) who reported that there were no significant effects following six weeks of Echinacea supplementation for nitrite $\left(\mu \mathrm{mol} \cdot \mathrm{L}^{-}\right.$ $1)$.

In the present work, the nitro blue tetrazolium test (NBT) was used to investigate the effect of Echinacea on production of ROS by PBM, as showed in (Table 6), there is a marked increase in ROS at $2^{\text {nd }}, 4^{\text {th }}$ and $6^{\text {th }}$ week compared to control group. These findings are agreed with those obtained by (Zhai et al., 2007), Echinacea Purified polysaccharides could enhance the production of oxygen radicals, proinflammatory cytokines and inflammatory mediators by macrophages and neutrophils.
In the present work, the effect of dietary supplementation of Echinacea on susceptibility to infections was investigated by challenge test as shown in Tables (7 and 8); the morbidity rate was $(80.3 \%)$ in control group, while it was $(46.4 \%)$ in Echinacea in supplemented group. The mortality rate was $(60 \%)$ in the control, while it was $(26.7 \%)$ chickens died in the Echinacea dietary supplemented group. The results revealed that there was a significant reduction in E. coli count in the spleen, liver and intestine of chickens fed on supplemented ration with Echinacea when compared with the control group. These findings are in accordance with that reported by (Savage et al., 1996) who reported that supplementation with oligosaccharides may have a prebiotic effect through an increase in production of lactic acid, thus increasing the proliferation of beneficial bacteria and reducing the presence of Gram-negative bacteria also Sullivan et al. (2008) found that oral administration with Echinacea purpurea reduces bacterial burden in the spleen of mice infected by listeria monocytoenes demonstrating its efficacy in vivo.

In conclusion, Echinacea might be used as growth promoters in broiler chickens as it improve body weight gain stimulate leukocyte production, stimulate globulin production, stimulate humeral immunity by increasing the 
antibody titer against ND and AIV vaccine as well as enhance the innate immunity by stimulating the PBM function as phagocytic activity, fungicidal activity and production of both of ROS and NO. Echinacea have the ability to protect broiler chickens from virulent as E. coli.

\section{References}

Allen P.C. (2003): Dietary supplementation with Echinacea and development of immunity to challenge infection with coccidia. Parasitol. Res. 91:74-78.

Anderson, D.P and Siwicki, A.K. (1995): Basic haematology and serology for fish health programs. Diseases in Asian Aquaculture II, Fish Health Section, Asian Fisheries Society, Manila, Philippines. pp. 185-202. In:M. Shariff, J.R. Author and R.P. Subasinghe. (eds.)

Bakerman, A.S. (1984): Determination of total protein.In: $\mathrm{ABC}, \mathrm{s}$ of interpretative laboratory data, $2^{\text {nd }}$ edition, Griffin and Tilghman, pp: 374.

Barbara, M.; Bohmer, H.; Salisch, B.R.; Paulicks F.X. and Roth, (2009): Echinacea purpurea as a potential immunostimulatory feed additive in laying hens and fattening pigs by intermittent application. Livestock Sci., 122: 8185.

Barrett, B. (2003): Medicinal properties of Echinacea: A critical review. Phytomed., 10:66-86.

Blond,D.; Raoul, H.; Grand R.Le. and Dormont D. (2000): Nitric oxide synthesis enhances human immunodeficiency virus replication in primary human macrophages. J. Virol., 74:8904-8912.

BohmerB.M, Salisch H, Paulicks B.R. and Roth F.X. (2009): Echinacea purpurea as a potential immunostimulatory feed additive in laying hens and fattening pigs by intermittent application. Livest. Sci. 122:81-85.

Cundell, D.R, Matrone, M.A, Ratajczak, P. and Pierce J.D., (2003): The effect of aerial parts of Echinacea on the circulating white cell levels and selected immune functions of the aging male Sprague-Dawleyrat.Int Immunopharmacol; 3:1041-1048.

Currier N.L, Lejtenyi $D$ and Miller S.C. (2003): Effect over time of in-vivo administration of the polysaccharide arabinogalactan on immune and hemopoietic cell lineages in murine spleen and bone marrow. Phytomedicine, 10:145153.

$\begin{array}{ccc}\text { Dehkordi S.H, Fallah V. and } & \text { V. } \\ \text { Dehkordi } & \text { S.H. } & \text { (2011): }\end{array}$ Enhancement of broiler performance and immune response by Echinacea purpurea supplemented in diet, Department of Pharmacology, School of Veterinary Medicine, Shahrekord University, Shahrekord, Iran, Pharma Technology, 3: 1-14..

Elmowalid, G (2012): A simple method for generation of functional sheep peripheral blood monocytesderived-macrophages in vitro. Global veterinaria 9 (5) : 590-599. 
Elmowalid ,G., Amar, A.M., Attia, A.(2013) : Nigella sativa seed extract,Enhancement of sheep macrophage immune functions in vitro Department of Bacteriology, Immunology and Mycology, Faculty of Veterinary Medicine, Zagazig University, Zagazig, Sharkia Governorate, Egypt. Research in Veterinary Science 95 (2013) 437-443.

Feizi A. and Dadian F. (2012): The effects of Echinacea purpurea dried extract on humoral immune response of broiler chicks to Newcastle vaccination. African Journal of Biotechnology.

Goel, V.; Chang, C.; Slama, J.; Barton, R.;. Bauer, R.; Gahler, R. and Basu, T.K.(2002): Echinacea stimulates macrophage function in the lung and spleen of normal rats. J. Nutr. Biochem., 13, 487-492.

Grievink, H.W., Luisman T, Kluft $C$, Moerland $M$. and Malone K.E., (2016): Comparison of three isolation techniques for human peripheral blood mononuclear cells: Cell recovery and viability, population composition, and cell functionality," Biopreservation and Biobanking. Oct;14(5):410-415. Epub 2016 Apr 22.

Hudson J.B.,(2012): Applications of the phytomedicine Echinacea purpurea (Purple Coneflower) in infectious diseases. $\mathrm{J}$ Biomed Biotechnol.; 2012:769896. doi: 10.1155/2012/769896.

Jahanian E., Jahanian R. Reza Rahmani H. and Alikhani $M$. (2014): Dietary supplementation of
Echinacea purpurea powder improved performance, serum lipid profile, and yolk oxidative stability in laying hens Journal of Applied Animal Research, 45:1, 45-51.

Landy N. Ghalamkari G.h., Toghyani M. and Moattar F., (2011): The effects of Echinacea purpurea L. (purple coneflower) as an antibiotic growth promoter substitution on performance, carcass characteristics and humoral immune response in broiler chickens Young Researcher Club, Islamic Azad University, Khorasgan Branch, Isfahan, Iran. Department of Animal Science, Khorasgan Branch, Islamic Azad University, Isfahan, Iran. Faculty of Pharmacy, Isfahan University of Medical Sciences, Isfahan, Iran.

Maass N, Bauer J, Paulicks B.R, Bohmer B.M. and Mair D.A. (2005): Efficiency of Echinacea purpurea on performance and immune status in pigs. J. Anim. Physiol. Anim. Nutr., 89:244.

Maisa M. Gharieb and Fatma $M$. Youssef (2014): Effect of echinacea purpurea and garlic on growth performance, immune response, biochemical and hematological parameters in broiler chicks. Assiut Vet. Med. J., 60 (140).

McCreadie, J.W. Adler, P.H. ,Hamada, N. and Grillet M.E.(2006): Sampling and statistics in understanding distributions of black fly larvae (Diptera: Simuliidae) Acta Entomol. Serbica (Suppl), pp. 89-96. 
Miller PJ, Koch G.(2013): Newcastle Disease. In: Swayne DE, editor. Diseases of poultry. 13th ed. Oxford, UK: Wiley-Blackwell. pp. 68-107.

Elmowalid, Gamal A., (2012): Simple method for generation of functional sheepmonocytes-derived macrophages in vitro. Global Veterinaria 9 (5), 590-599.

Miraghaee, S.S., Heidary B., Almasi H., Shabani A., Elahi M. and Nia M.H.M. (2011): The effects of Nigella sativa powder (blackseed) and Echinacea purpurea (L.) Moenchextract on performance, some blood biochemical and hematological parameters in broiler chickens. Afr. J. Biotechnol., 10 (82): 19249-19254.

Mishima, S.; Saito, K.; Maruyama, H.; Inoue, M.; Yamashita, T.; Ishida, T and Gu, Y. (2004): Antioxidant and immuno-enhancing effects of Echinacea purpurea. Biol Pharm Bull., 27: 1004-1009.

Nasir, Z. and Grashorn, M.A. (2009): Echinacea: Apotential feed and water additive in poultry and swine production. Arch. Geflügelk. 73(3).

O'Neill, W.; McKee, S. and Clarke, A.F. (2002): Immunological and haematinic consequences of feeding a standardised Echinacea (Echinacea angustifolia) extract to healthy horses. Equine Vet J.,34: 222-227.

Peck, R., (1985): A one plate assay for macrophage bactericidal activity. Journal of Immunological Methods, 82: 131-139.

Percival, S.S. (2000): Use of Echinacea in medicine. Biochem. Pharmacol., 60:155-158.

Porchezhian, T. and Punniamurthy, N. (2006): Effect of Oral Levamisole Hydrochloride on Humoral Immune Response and Serum proteins of Broilers. Journal of Animal and Veterinary Advances, 5 (10): 873-874.

Przybilla $P$ and Weiss J (1998): Pflanzliche Futterzusatzstoffe in der Schweinemast. Die Mastleistung natürlich verbessern.

DGSMagazin.40:52-57.

Redondo, L. (2000): La Equinácea purpúrea: una alternative real para estimular el sistema inmunológico Review. Fitoterapia., 1: 15-24.

Roth-Maier, D.A., Böhmer, B.M., Maaß, N., Damme, K. and Paulicks, B.R. (2005):.Efficiency of Echinacea purpurea on Performance of Broilers and Layers. Arch.Geflügelk, 69(3): 123-127.

Savage, T. F., Cotter, P. F. and Zakrzewska, E. I. (1996): The Effect of Feeding Mannan Oligosaccharide on Immunoglobulins, Plasma Ig $\mathrm{G}$ and Bile Ig A, of Wrolstad MW mal Turkeys. Poult. Sci.,75: 143.

Skaudickas D, Kondrotas A.J, Baltrusaitis $K$. and Vaitiekaitis G., (2003): Effect of Echinacea (Echinacea Purpurea L. Moench) preparations on experimental prostate gland. Medicina (Kaunas). 39 (8): 761-766. 
Stoskopf, K.M. (1993): Fish supplementation for nitrite $\left(\mu \mathrm{mol} \cdot \mathrm{L}^{-}\right.$ Medicine. W.B. Saunders $\left.{ }^{1}\right)$ Published online 2012 Nov 19. Company, Harcoort Bruce Javanrich. Incist Ed.

Sullivan, A.M, Laba, J.G, Moore, J.A and Lee, T.D. (2008): United States Department of Echinacea induced macrophage activation.

Immunopharmacol.Immunotoxicol., 30 (3): 553-574.

Teuber, M. (2001): Veterinary use and antibiotic resistance. Curr. Opin. Microbiol., 4:493-499. doi:10.1186/1550-2783-9-S1-P21J Int Soc Sports Nutr., 9 (Suppl 1): P21.

Threlfall, E.J.; Ward, L.R.; Frost, J.A. and Willshaw, G.A. (2000): The emergence and spread of antibiotic resistance in foodborne bacteria. Int. J. Food. Microbiol., 62:1-5.

Tyler, D. Martin,Micha, E.S. Press.

Green,Malcolm,

T. Zhai Z, Liu Y, Wu L, Senchina Whitehead,Timothy, P. Scheett, Michael, J. Webster, and Geoffrey, M. Hudson, (2012): There were no significant interaction, group, or time effects observed following six weeks of Agriculture Food Safety and Inspection Service (USDA FSIS). (2010): Complicance guide for controlling Salmonella and Campylobacter in poultry, $3^{\text {rd }} 38$ edition. Accessed July 2010.<http://www.fsis.usda.gov/ PDF/Compliance Guide Controling Salmonella Campylobacter Poultry 0510.pdf.

Young, D. S. (1997): Effect of preanalytical variables on clinical laboratory tests. $2^{\text {nd }}$ Ed., AACC D.S, Wurtele E.S, Murphy P.A, Kohut M.L. and Cunnick J.E (2007): Enhancement of innate and adaptive immune functions by multiple Echinacea species. J. Med. Food, 10: 423-434. 


\section{تقييم تاثير نبات الاثنسيا كمعل مناعي على الاستجابة المناعية فى دجاج التسمين

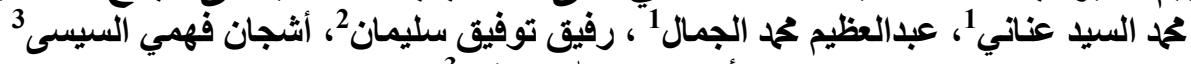

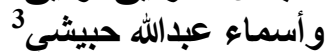

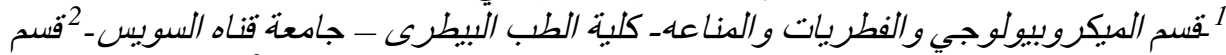

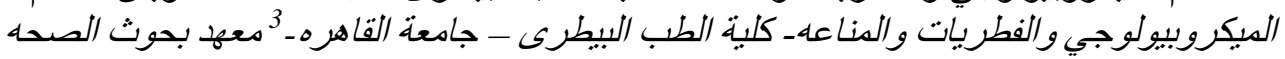 الحبيوانيه بالدقى اليطرى}

معدلات المناعة الطبيعية نوفر دور هام في رفع كفاءة الجهاز المناعي في الطيور بدون حدوث اثار

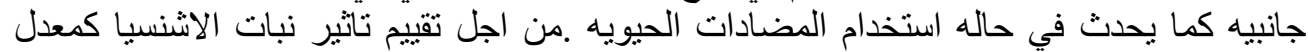

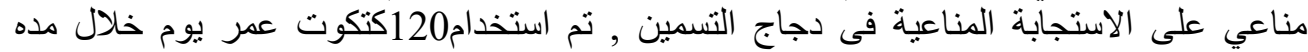

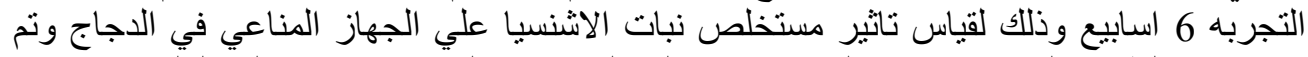

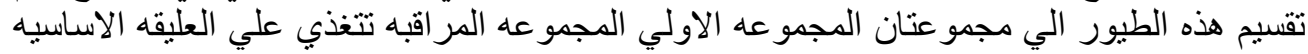

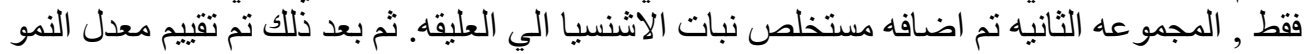

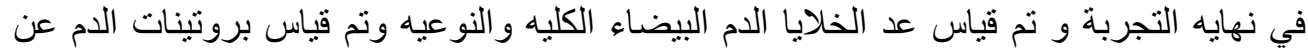

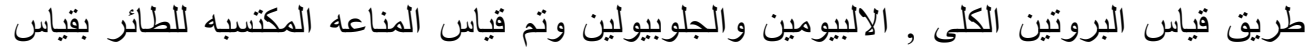

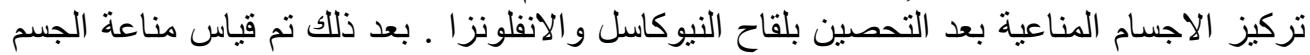

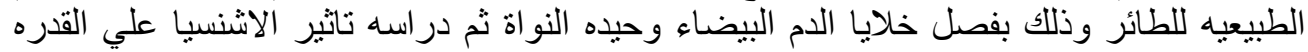

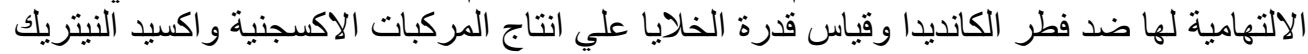

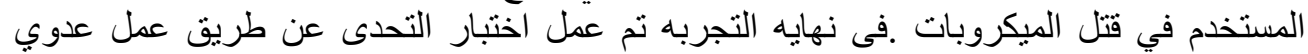

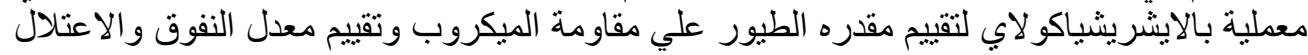

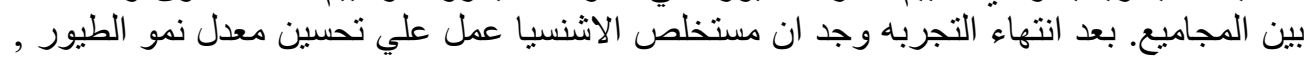

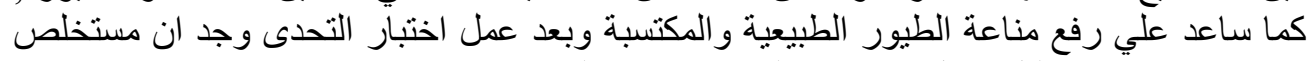
الاشنسيا ساعد في تقليل معدل الاصابة بالعدوى ونقوق الطيور الطية 